\title{
The role of anticonvulsant drugs in regional anaesthesia for hip surgery in children with cerebral palsy and concomitant epilepsy
}

\author{
V.V. Evreinov ${ }^{1}$, T.A. Zhirova ${ }^{2}$ \\ ${ }^{1}$ Ilizarov National Medical Research Centre for Traumatology and Orthopedics, Kurgan, Russian Federation \\ ${ }^{2}$ V.D. Chaklin Ural Institute of Traumatology and Orthopedics, Ekaterinburg, Russian Federation
}

\begin{abstract}
Children with cerebral palsy (CP) typically suffer from epileptic seizures as a co-occurring condition to be addressed with antiepileptic drugs (AED) on a long-term basis. The incidence of coagulation disorders related to AED in children with $\mathrm{CP}$ is evaluated to range from nearly $4 \%$ to $20.7 \%$. Surgery at the hip in CP children requires prolonged epidural analgesia that can be associated with serious adverse events such as epidural hematoma. The evidence for the use of continuous peripheral nerve blockade in children with CP, however, is limited. Purpose To evaluate the effect of AED on hemostasis and safe use of regional anaesthesia techniques at hip surgery in children with $\mathrm{CP}$ and concomitant epilepsy. Material and methods A prospective randomized study included 45 children with $\mathrm{CP}$ who underwent surgical treatment for spastic hip displacement. According to a type of anesthesia used and a co-occurring condition diagnosed, patients were allocated into 3 groups of 15 participants each: PEA group (control), children with no history of epilepsy receiving prolonged epidural analgesia (PEA); PEA-E group, children with epilepsy receiving AED and PEA; CFSB-E group, children with epilepsy receiving AED and a continuous femoral plus single-shot sciatic nerve block. Hemodynamic and laboratory findings, a need for blood components and complications were evaluated. Results A preoperative fibrinogen level was significantly higher in controls (PEA group), whereas PEA-E and CFSB-E patients showed reduced levels of circulating fibrinogen, prolonged aPTT and decreased coagulation index with negative values measured during major surgical phase. Conclusion Although basic anticonvulsant therapy with use of AED in children with cerebral palsy has been found to be associated with tendency to hypocoagulation evaluated with laboratory tests, neither clinically significant coagulopathy nor a greater risk of hemorrhagic complications have been identified with use of regional anaesthesia at hip joint operations.

Keywords: cerebral palsy, childhood, concomitant epilepsy, prolonged femoral nerve analgesia, prolonged epidural analgesia, hip surgery
\end{abstract}

\section{INTRODUCTION}

Children with cerebral palsy (CP) typically suffer from epilepsy as a co-occurring condition with seizures reported in $33 \%$ [1] of the cases to be addressed with antiepileptic drugs (AED) on a longterm basis. The incidence of coagulation disorders related to AED in children with $\mathrm{CP}$ is evaluated to range from nearly $4 \%$ to $20.7 \%[2,3]$. Major orthopaedic procedures performed for patients with low nutritional status, baseline anemia [1, 4-10], as well as AED related side effects on hemopoiesis, hemostasis and synthetic function in the liver [11, 12] make caring for these patients more difficult with special anaesthetic considerations required to accommodate his or her disabilities and effective postoperative pain management.

Inhalational anaesthesia with mechanical ventilation combined with prolonged epidural block is the most common practice in surgical treatment of spastic hip displacement involving multilevel muscle and tendon plasty in CP patients. The safe use of the technique has been shown in large-scale investigations [13-15]. However, the question whether the technique is appropriate for children with epilepsy taking AED and being at a higher risk of hemorrhagic complications (epidural hematoma) is still unanswered [16-18]. The safe use of prolonged peripheral nerve block in patients receiving AED therapy has been underinvestigated with no comparative data on use of regional anaesthesia techniques in the cohort of patients available [19].

The purpose of the study was to evaluate the effect of AED on hemostasis and safe use of regional anaesthesia techniques at hip surgery in children with $\mathrm{CP}$ and concomitant epilepsy.

\section{MATERIAL AND METHODS}

The null hypothesis was based on the assumption that AED therapy does not have any effect on hemostasis and play any role in hemorrhagic complications in the settings of prolonged epidural anaesthesia or peripheral nerve blocks at hip surgeries in children with CP and concomitant epilepsy. 
Design A prospective randomized comparative clinical trial. Randomization was performed by generating random numbers (www.randomization.com).

Study object Children with moderate and severe CP (graded according to GMFCS) who underwent unilateral multilevel interventions on lower limbs for spastic hip displacement/subluxation.

The study was performed at the Federal State Budgetary Institution «Russian Ilizarov Scientific Center for Restorative Traumatology and Orthopaedics» from January to December 2019, received a favourable opinion from the relevant research ethics committee and conducted in accordance with ethical principles for medical research involving human subjects stated in the Declaration of Helsinki and the rules of Good Clinical Practice approved by Order No. 200n dated April 01, 2016 of the Ministry of Health of the Russian Federation On Approval of Rules for Good Clinical Practice [20]. Written informed consent was obtained from all patients or legal guardians for publication of the findings without identifying details.

Inclusion criteria:

1) age 3 to 17 years;

2) level III-V GMFCS motor functioning;

3) unilateral palliative or reconstructive hip interventions combined with multilevel muscle and tendon plasty of the lower limb;
4) concomitant epilepsy and AED therapy.

Exclusion criteria Bilateral single event reconstructive hip interventions.

Characterization of patients and methods of study

The study included 45 children, from them, 31 male and 14 female participants. According to a type of perioperative analgesia used and a co-occurring condition diagnosed, patients were allocated into 3 groups of 15 participants each being comparable by major parameters effecting the outcome. Demographic patients' characteristics are presented in Table 1. Group I (PEA, controls) consisted of children with no history of epilepsy receiving Prolonged Epidural Analgesia (PEA, $n=15$ ). Groups II and III (PEA-E and CFSB-E groups) suffered from epileptic seizures and received basic AED therapy. PEA was also provided for children with epilepsy (PEA-E, $n=15$ ) (Group II). A continuous femoral plus single-shot sciatic nerve block was used for Group III (CFSB-E, $\mathrm{n}=15$ ).

Of 45 participants, 30 (67 \%) suffered from epilepsy and received basic AED therapy (PEA-E and CFSB-E patients) that persisted during preoperatrive and postoperative periods. AED monotherapy was administered for 12 out of 15 PEA-E children (80 \%), and 3 out of 15 (20\%) took more than one AED. AED monotherapy was administered for 11 out of 15 CFSB-E children (73\%), and 4 out of 15 (27\%) received combined AED therapy (Table 2).

Table 1

Demographic patients' characteristics

\begin{tabular}{|c|c|c|c|c|c|c|c|c|c|c|c|c|c|c|}
\hline \multirow{3}{*}{ Group } & \multicolumn{4}{|c|}{ Sex* } & \multirow{3}{*}{$\begin{array}{c}\text { Age } \\
\text { (years) }^{* * *}\end{array}$} & \multirow{3}{*}{$\begin{array}{l}\text { Body } \\
\text { weight } \\
(\mathrm{kg})^{* * *}\end{array}$} & \multicolumn{4}{|c|}{$\begin{array}{c}\text { Risk evaluation according to the Moscow } \\
\text { Research Society of Anaesthesiology and } \\
\text { Intensive Care system* }\end{array}$} & \multicolumn{4}{|c|}{ GMFCS level* } \\
\hline & \multicolumn{2}{|c|}{ Male } & \multicolumn{2}{|c|}{ Female } & & & \multicolumn{2}{|c|}{ III степень } & \multicolumn{2}{|c|}{ IV степень } & \multicolumn{2}{|c|}{ III-IV } & \multicolumn{2}{|c|}{$\mathrm{V}$} \\
\hline & abs. & $\%$ & abs. & $\%$ & & & abs. & $\%$ & abs. & $\%$ & abs. & $\%$ & abs. & $\%$ \\
\hline PEA & 8 & 53 & 7 & 47 & $9 \pm 4$ & $23.5 \pm 9.3$ & 11 & 73 & 4 & 27 & 12 & 80 & 3 & 20 \\
\hline PEA-E & 11 & 73 & 4 & 27 & $8.4 \pm 3.4$ & $19 \pm 5.6$ & 8 & 53 & 7 & 47 & 9 & 60 & 6 & 40 \\
\hline CFSB-E & 12 & 80 & 3 & 20 & $9.1 \pm 3.8$ & $22.2 \pm 11.8$ & 10 & 67 & 5 & 33 & 8 & 53 & 7 & 47 \\
\hline
\end{tabular}

Criterium 2; single-factor analysis of variance, $p>0.05$

Table 2

AED therapy used for the patients

\begin{tabular}{|c|c|c|c|c|c|}
\hline \multirow{2}{*}{\multicolumn{2}{|c|}{ Group }} & \multicolumn{2}{|c|}{ PEA-E } & \multicolumn{2}{|c|}{ CFSB-E } \\
\hline & & \multirow{2}{*}{$\frac{\text { abs. }}{12}$} & \multirow{2}{*}{$\begin{array}{c}\% \\
80 \\
\end{array}$} & \multirow{2}{*}{$\frac{\text { abs. }}{11}$} & \multirow{2}{*}{$\begin{array}{l}\% \\
73 \\
\end{array}$} \\
\hline Tyne of therany & Monotherapy & & & & \\
\hline туре of therapy & Combined therapy & 3 & 20 & 4 & 27 \\
\hline \multirow{7}{*}{ AED } & Phenytoin & 0 & & 1 & \\
\hline & Sulthiame & 1 & & 0 & \\
\hline & Valproic acid & 8 & & 7 & \\
\hline & Carbamazepine & 2 & & 0 & \\
\hline & Levetiracetam & 4 & & 6 & \\
\hline & Topiramate & 2 & & 3 & \\
\hline & Oxcarbamazepine & 0 & & 2 & \\
\hline
\end{tabular}

Criterium 2, $p>0.05$ 
Preoperative risk evaluation was performed with the Moscow Research Society of Anaesthesiology and Intensive Care (MRSAIC) system from the perspective of anaesthesiology. MRSAIC risk grade III was identified in 11 out of 15 PEA patients (73\%), MRSAIC risk grade IV detected in 4 out of 15 PEA patients (27\%). MRSAIC risk grade III was identified in 8 out of 15 PEA-E patients (53 \%) and MRSAIC risk grade IV detected in 7 out of 15 PEA-E patients (47\%). Ten of 15 CFSB-E patients (67\%) were diagnosed with MRSAIC risk grade III, and 5 out of 15 (33 \%) had MRSAIC risk grade IV ( $p>0.05)$.

All children were operated under general inhalational anaesthesia and mechanical ventilation combined with epidural blockade in PEA and PEA-E patients and peripheral blockade in CFSB-E cases. Propofol, fentanyl, rocuronium bromide were used for induction of general anesthesia with a dose adjusted according to age and body-weight. No muscle relaxants were employed for induction with regional blocks administered during narcotic anaesthesia. Fentanyl infusion consisting of the medium dose of $5.0(1.9) \mathrm{mcg} / \mathrm{kg}, 5.4(1.9) \mathrm{mcg} / \mathrm{kg}, 5.7$ (2.0) $\mathrm{mcg} / \mathrm{kg}$ in PEA, PEA-E and CFSB-E groups, respectively, prior to tracheal intubation ( $p>0,05)$. Sevoflurane (Sevorane ${ }^{\circledR}$, Abbott Laboratories, UK) was used as an inhalational agent for maintenance. Epidural infusion of a local anesthetic (ropivacaine $0.5 \%$ ) with bolus $2 \mathrm{mg} / \mathrm{kg}$ via G20 catheter placed at the dermatome level corresponding to the surgical site of L3-L4 was performed furtheron with $1 / 2$ of initial volume every two hours in PEA and PEA-E groups. Ropivacaine $0.15 \%$ was infused via G20 perineural catheter placed in projection of the femoral nerve. Dorso-dorsal sciatic nerve block (according to Raj) was produced intraoperatively. The neuromuscular blockades were monitored with a nerve stimulatoris. Total anaesthetic dose applied for the neuromuscular blockades was $2 \mathrm{mg} / \mathrm{kg} 0.15 \%$ ropivacaine with $1 / 2$ estimated volume per each nerve.

The mean intraoperative dose of ropivacaine was 0.6 (0.2) mg/kg/h in PEA group, 0.7 (0.2) mg/kg/h in PEA-E patients and $0.7(0.2) \mathrm{mg} / \mathrm{kg} / \mathrm{h}$ in CFSB-E group ( $p>0.05)$. Continuous wound infusion of ropivacaine $0.2 \% 0.3 \mathrm{mg} / \mathrm{kg} / \mathrm{h}$ using an elastomeric pump was produced at early postoperative period at the department of anaesthesiology and intensive care with local anaesthetic delivered at a rate of $6.5(2.5) \mathrm{mg} / \mathrm{h}, 6.7(4.1) \mathrm{mg} / \mathrm{h}$ and $6.3(2.7) \mathrm{mg} / \mathrm{h}$ in PEA, PEA-E and CFSB-E groups, respectively $(p>0.05)$. All patients were extubated on the operating table at the end of the surgical procedure and transferred to A\&ICU with spontaneous breathing autonomy. Surgical injury evaluation was based on external blood loss calculated with gravimetric method and the number of orthopaedic manipulations produced in different anatomical sites at one surgical sessions (Table 3). Tranexamic acid (15 mg/kg body weight) was used perioperatively for conservative hemostasis and 6 hours after the first administration.

Parenteral fluid therapy involved the intravenous administration of crystalloid solutions and showed no statistically significant differences between the groups. Intraoperative fluid rates were 24.2 (10.5) $\mathrm{mL} / \mathrm{kg} / \mathrm{h}$ in REA group, $30.4(9.8) \mathrm{mL} / \mathrm{kg} / \mathrm{h}$ in PEA-E patients and $30(10.2) \mathrm{mL} / \mathrm{kg} / \mathrm{h}$ in CFSB-E patients $(p>0.05)$. At early postopertaive period, intravenous fluid rates were $2.1(0.5) \mathrm{mL} / \mathrm{kg} / \mathrm{h}, 2.6(0.7) \mathrm{mL} /$ $\mathrm{kg} / \mathrm{h}, 2.2(0.5) \mathrm{mL} / \mathrm{kg} / \mathrm{hiin}$ PEA, PEA-E and CFSB-E groups, respectively $(p>0.05)$. The transfusion of whole blood or packed red blood cells was indicated in acute anemia caused by precipitous blood loss with a 25-30\% decrease in circulating blood volume, hematocrit $<25 \%$, hemoglobin $<70-80 \mathrm{~g} / \mathrm{L}$ and blood circulation disorders.

\section{Assessment criteria:}

1) standard basic hemodynamics: the mean arterial pressure (MAP), heart rate measured with anesthesia monitor;

2) laboratory tests for hemoglobin, platelets count, hemostasiography and thromboelastography;

3) need in blood components;

4) complication rate.

Table 3

Surgical injury evaluation

\begin{tabular}{|c|c|c|c|c|c|c|c|c|}
\hline \multirow{3}{*}{ Group } & \multirow{3}{*}{$\begin{array}{l}\text { Blood loss } \\
\quad(\mathrm{mL})\end{array}$} & \multirow{3}{*}{$\begin{array}{c}\text { Volume of } \\
\text { blood loss } \\
\text { (\% of circulating } \\
\text { blood volume) }\end{array}$} & \multicolumn{6}{|c|}{ Number of patients } \\
\hline & & & \multicolumn{2}{|c|}{$\begin{array}{l}1 \text { manipulation at } \\
1 \text { operative session }\end{array}$} & \multicolumn{2}{|c|}{$\begin{array}{c}2 \text { to } 5 \text { manipulations at } \\
1 \text { operative session }\end{array}$} & \multicolumn{2}{|c|}{$\begin{array}{c}6 \text { to } 10 \text { manipulations at } \\
1 \text { operative session }\end{array}$} \\
\hline & & & abs. & $\%$ & abs. & $\%$ & abs. & $\%$ \\
\hline PEA & $120.7 \pm 69.2$ & $7 \pm 3.3$ & 1 & 6.7 & 10 & 66.7 & 4 & 26.6 \\
\hline PEA-E & $92.3 \pm 31.9$ & $6.5 \pm 2.1$ & 2 & 13.3 & 11 & 73.4 & 2 & 13.3 \\
\hline CFSB-E & $102.3 \pm 50.8$ & $6.5 \pm 2.6$ & 0 & 0 & 13 & 86.7 & 2 & 13.3 \\
\hline
\end{tabular}

Criterium 2; single-factor analysis of variance, $p>0.05$ 


\section{Timings of assessment}

Preoperatively, perioperatively (major phase of surgery) and at 6 o'clock in the morning on the first postoperative day (FPD).

Statistical data analysis was performed using StatPlusPro6 computer program. All samples of quantitative data were tested to determine normality of distribution in the groups. The data obtained were summarized as means \pm standard deviations (SD) in normal distribution; numerical data were presented with median, the first quartile and the third quartile
(Me Q1; Q3) when distribution was different from the norm. Single-factor analysis of variance was used for comparisons between the groups followed by a stepwise multiple comparisons procedure using the Newman-Keuls method or Bonferroni correction. The Kruskal-Wallis test, a non-parametric method, was used for multiple comparisons if the data did not have the Gaussian distribution. To assess quality characteristics and compare group share we used test $\Sigma 2$. For calculations, a significance level $\leqslant$ of $5 \%(p \leqslant 0.05)$ was adopted with the null hypothesis rejected.

\section{RESULTS}

No statistically significant and clinically important differences in hemodynamics were observed between the groups at the stages of observations. The mean values of the parameters measured were within age related reference interval for the cohort of patients (Table 4).

No significant differences in hemotological findings were observed between the study groups. Mild posthemorrhagic anemia was observed in the patients with insignificant decrease in hemoglobin levels caused by perioperative blood loss and moderate haemodilution. Statistically significant differences detected at the major surgical phase could be considered as clinically important. None of the patients required blood components transfusion.

Analysis of hemostasiological parameters showed statistically significant differences in preoperative fibronogen levels in PEA group. The mean fibrinogen value in the group measured $2.7(0.7) \mathrm{g} / \mathrm{L}$, whereas PEA-E and CFSB-E patients had fibrinogen at the lower limit of reference interval measuring 2 $(0.7)$ and $2.1(0.6) \mathrm{g} / \mathrm{L}$, respectively $(\mathrm{p}<0.05)$. Fibrinogen was shown to decrease in all groups due to perioperative blood loss and was below the lower limit of reference range in patients taking AEDs demonstrating statistically signifficant differences in measurements of controls $(\mathrm{p}<0.05)$. Fibrinogen level was low in all groups at the major surgical phase due to perioperative blood loss and was below the lower limit of reference range in patients taking AEDs demonstrating statistically signifficant differences in measurements of controls. No statistically and clinically significant differences in fibrinogen levels were noted between the study groups during postoperative period $(\mathrm{p}>0.05)$.

Activated partial thromboplastin time (aPTT) was statistically more significant in PEA-E patients as compared to the two other groups $(p=0,014)$. The mean aPTT was recorded at the upper limit of reference interval measuring 37 (4) seconds, whereas the mean aPTT was 34 (3) seconds in CFSB-E patients and 33 (4) seconds in controls with no statistically significant differences noted $(\mathrm{p}>0.05)$. This can be associated with a lower statistical power of our study. Dynamics in major laboratory tests is presented in Table 5.

No statistically and clinically significant differences in thromboelastographic findings were observed between the study groups at all stages of observation $(\mathrm{p}>0.05)$. However, the coagulation index (CI) as an integral parameter showed a preoperative tendency to hypocoagulation in patients receiving AED therapy (PEA-E and CFSB-E groups) and could be responsible for an adverse effect on the overall coagulation capability from continous AED administration. All the parameters were within reference range with tendencies recognized being of clinical interest showing no signs of rampancy. The data are presented in Table 6 .

It should be noted that none of the patients developed a hemorrhagic complication.

Table 4

Hemodynamics in the groups of patients

\begin{tabular}{|c|l|c|c|c|}
\hline Group & \multicolumn{1}{|c|}{ Parameter } & Preoperatively & Perioperatively & FPD \\
\hline \multirow{2}{*}{ PEA } & MAP (mmHg) & $72 \pm 8$ & $60 \pm 8$ & $71 \pm 7$ \\
\cline { 2 - 5 } & Heart rate (beats per minute) & $124 \pm 10$ & $106 \pm 11$ & $112 \pm 24$ \\
\hline \multirow{2}{*}{ PEA-E } & MAP (mmHg) & $73 \pm 3$ & $58 \pm 12$ & $71 \pm 9$ \\
\cline { 2 - 5 } & Heart rate (beats per minute) & $113 \pm 15$ & $98 \pm 15$ & $110 \pm 17$ \\
\hline \multirow{2}{*}{ CFSB-E } & MAP (mmHg) & $73 \pm 4$ & $60 \pm 6$ & $77 \pm 10$ \\
\cline { 2 - 5 } & Heart rate (beats per minute) & $112 \pm 16$ & $104 \pm 11$ & $104 \pm 15$ \\
\hline
\end{tabular}

Single-factor analysis of variance, $p>0.05$ 
Table 5

Dynamics in standard laboratory tests

\begin{tabular}{|l|c|c|c|c|c|c|c|c|c|}
\hline \multirow{2}{*}{ Parameter } & \multicolumn{3}{|c|}{ Preoperatively } & \multicolumn{3}{c|}{ Perioperatively } & \multicolumn{3}{c|}{ FPD } \\
\cline { 2 - 10 } & PEA & PEA-E & CFSB-E & PEA & PEA-E & CFSB-E & PEA & PEA-E & CFSB-E \\
\hline aPTT, s & $32(4)$ & $35(6)$ & $34(5)$ & $33(4)^{*}$ & $37(4)^{*}$ & $34(3)^{*}$ & $34(4)$ & $34(4)$ & $32(4)$ \\
\hline PTT, s & $\begin{array}{c}12.4 \\
(1.8 ; 12.9)\end{array}$ & $13.1(1.2)$ & $12.4(0.9)$ & $13.2(0.8)$ & $13.8(1.2)$ & $13.5(1.3)$ & $15.4(2.0)$ & $14.2(2.1)$ & $14.5(1.6)$ \\
\hline TT, s & $\begin{array}{c}16.1 \\
(15.1 ; 21.5)\end{array}$ & $\begin{array}{c}17.8 ; 21.6) \\
\end{array}$ & $18.5(3.8)$ & $20.1(5.7)$ & $21.3(5.9)$ & $21.1(4.4)$ & $17.1(4.5)$ & $18.9(5.1)$ & $17.1(3.8)$ \\
\hline Fibrinogen, g/L & $2.7(0.7)^{*}$ & $2.0(0.7)^{*}$ & $2.1(0.6)^{*}$ & $2.1(0.5)^{*}$ & $1.7(0.6)^{*}$ & $1.6(0.5)^{*}$ & $3.7(1)$ & $2.9(1)$ & $2.9(1)$ \\
\hline PAG III, \% & $108(17)$ & $95(16)$ & $104(12)$ & $82(12)$ & $83(17)$ & $79(10)$ & $94(15)$ & $96(11)$ & $98(13)$ \\
\hline Platelets, $\times 10^{9}$ & $353(144)$ & $306(85)$ & $279(57)$ & $294(77)$ & $270(66)$ & $256(73)$ & $293(73)$ & $270(81)$ & $268(80)$ \\
\hline Hemoglobin, g/L & $128(11)$ & $133(11)$ & $132(8)$ & $100(12)^{*}$ & $112(12)^{*}$ & $108(9)^{*}$ & $107(12)$ & $116(13)$ & $117(12)$ \\
\hline
\end{tabular}

* Single-factor analysis of variance; the Newman-Keuls method, $\mathrm{p}<0.05$.

Table 6

Dynamics in thromboelastography

\begin{tabular}{|c|c|c|c|c|c|c|c|c|c|}
\hline \multirow{2}{*}{ Parameter } & \multicolumn{3}{|c|}{ Preoperatively } & \multicolumn{3}{|c|}{ Intaoperatively } & \multicolumn{3}{|c|}{ FPD } \\
\hline & PEA & PEA-E & CFSB-E & PEA & PEA-E & CFSB-E & PEA & PEA-E & CFSB-E \\
\hline MU & $7.1(5.2)$ & $\begin{array}{c}7.2 \\
(5.2 ; 8.8) \\
\end{array}$ & $6.6(2.1)$ & $\begin{array}{c}6.9 \\
(4.7 ; 8.5)\end{array}$ & 9) & 5) & $\begin{array}{c}7.4 \\
4.8 ; 9.7)\end{array}$ & $\begin{array}{c}5.5 \\
(4.4 ; 7) \\
\end{array}$ & 1) \\
\hline$T$ & 1 & $\begin{array}{c}1,8 \\
(1,7 ; 2,9)\end{array}$ & $2.7(1.4)$ & $\begin{array}{c}1.4 \\
(1.1 ; 2.0)\end{array}$ & 2 & $(1+)$ & $\begin{array}{c}1.5 \\
(1.3 ; 2.2)\end{array}$ & $\begin{array}{c}1.8 \\
(1.2 ; 2.4)\end{array}$ & $1.6(0.6)$ \\
\hline pit & 59 (19) & $54(1$ & $58(15)$ & $64(13)$ & $52(17)$ & 45 (13) & $63(16)$ & $\begin{array}{c}64 \\
(59 ; 70)\end{array}$ & $63(11)$ \\
\hline & 8 & 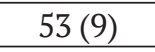 & & $57(7)$ & & & $62(6)$ & $60(9)$ & $61(10)$ \\
\hline CI & $\begin{array}{c}1.5 \\
(-4.7 ; 3.0) \\
\end{array}$ & $\begin{array}{c}-2.3 \\
(-4.5 ;-1.0 \\
\end{array}$ & $-1.6(3.4)$ & $\begin{array}{c}-0.5 \\
(-2.4 ; 1.5)\end{array}$ & $-2.9(3.7)$ & $-2.6(4.4)$ & $\begin{array}{c}-1.1 \\
(-.3 .6 ; 1.7)\end{array}$ & $\begin{array}{c}0.4 \\
(-0.6 ; 2.4) \\
\end{array}$ & $\begin{array}{c}0.5 \\
(-2.2 ; 1.7) \\
\end{array}$ \\
\hline 30 & $\begin{array}{c}2.7 \\
(0.3 ; 5.1) \\
\end{array}$ & $\begin{array}{c}1.4 \\
(0.6 ; 3.8) \\
\end{array}$ & $\begin{array}{c}3.3 \\
(0.7 ; 9.5) \\
\end{array}$ & $\begin{array}{c}4.2 \\
(0.7 ; 6.5) \\
\end{array}$ & $\begin{array}{c}0.3 \\
(0.1 ; 1.4) \\
\end{array}$ & $4.6(4.0)$ & $\begin{array}{c}0.3 \\
(0 ; 3.7)\end{array}$ & $\begin{array}{c}0.8 \\
(0.1 ; 2.7) \\
\end{array}$ & $\begin{array}{c}1.1 \\
(0.4 ; 3.8)\end{array}$ \\
\hline
\end{tabular}

\section{DISCUSSION}

Statistically significant differences in fibrinogen levels recorded preoperatively in patients receiving AED as compared to the patients taking no AED are likely to be associated with impaired liver function of protein synthesis due to continuous drug therapy. A relatively low coagulation capacity due to limited reserve of coagulation factors associated with AED administration and the elimination mechanisms can be responsible for increased aPTT in PEA-E group at the peak of blood loss and hemodilution during the major surgical phase. Most AED are metabolized in the liver with resultant toxic products (4-ene-Valproic acid, carbamazepine-10, 11-epoxide, etc.) that can cause drug-induced hepatitis with a long-term administration of the drugs [21-23]. AEDs are known to inhibit hepatic enzymes with low gastrointestinal absorption of vitamin $\mathrm{K}$ and folic acid contributing to deficient coagulation factors and megaloblastic anemia [24]. Alterations in hemostasiological parameters are likely to be influenced by continuous AED administration being clinically insignificant and having no risk of bleeding and associated adverse events with use of regional anaesthesia techniques that is on par with literature data $[13,14,15,25-26]$.

\section{CONCLUSION}

Basic anticonvulsant therapy with use of AED in children with cerebral palsy and concomitant epilepsy has been found to result in changes in laboratory tests and associated tendency to hypocoagulation with low fibrinogen levels, prolonged aPTT and and decreased coagulation index with negative values. Neither clinically significant coagulopathy nor a greater risk of hemorrhagic complications were associated with the changes detected in use of regional anaesthesia techniques at hip joint operations involving multilevel muscle and tendon plasty.

\section{REFERENCES}

1. Novak I., Hines M., Goldsmith S., Barclay R. Clinical prognostic messages from a systematic review on cerebral palsy. Pediatrics, 2012, vol. 130, no. 5, pp. e1285-e1312. DOI: 10.1542/peds.2012-0924. 
2. Abdallah C. Considerations in perioperative assessment of valproic acid coagulopathy. J. Anaesthesiol. Clin. Pharmacol., 2014, vol. 30, no. 1, pp. 7-9. DOI: 10.4103/0970-9185.125685.

3. Kumar R., Vidaurre J., Gedela S. Valproic acid-induced coagulopathy. Pediatr. Neurol., 2019, vol. 98, pp. 25-30. DOI: 10.1016/ j.pediatrneurol. 2019.04.019.

4. Sangermano M., D'Aniello R., Massa G., Albano R., Pisano P., Budetta M., Scuccimarra G., Papa E., Coppola G., Vajro P. Nutritional problems in children with neuromotor disabilities: an Italian case series. Ital. J. Pediatr., 2014, vol. 40, pp. 61. DOI: 10.1186/1824-7288-40-61.

5. Lopes P.A., Amancio O.M., Araújo R.F., Vitalle M.S., Braga J.A. Food pattern and nutritional status of children with cerebral palsy. Rev. Paul. Pediatr., 2013, vol. 31, no. 3, pp. 344-349. DOI: 10.1590/S0103-05822013000300011.

6. Perenc L., Przysada G., Trzeciak J. Cerebral palsy in children as a risk factor for malnutrition. Ann. Nutr. Metab., 2015, vol. 66, no. 4, pp. 224-232. DOI: 10.1159/000431330.

7. Hariprasad P.G., Elizabeth K.E., Valamparampil M.J., Kalpana D., Anish T.S. Multiple Nutritional Deficiencies in Cerebral Palsy Compounding Physical and Functional Impairments. Indian J. Palliat. Care, 2017, vol. 23, no. 4, pp. 387-392. DOI: 10.4103/1JPC. IJPC_52_17.

8. Gerstner T., Teich M., Bell N., Longin E., Dempfle C.-E., Brand J., König S. Valproate-associated coagulopathies are frequent and variable in children. Epilepsia, 2006, vol. 47, no. 7, pp. 1136-1143. DOI: 10.1111/j.1528-1167.2006.00587.x.

9. Köse G., Arhan E., Unal B., Ozaydin E., Guven A., Sayli T.R. Valproate-associated coagulopathies in children during short-term treatment. J. Child. Neurol., 2009, vol. 24, no. 12, pp. 1493-1498. DOI: 10.1177/0883073808331084.

10.Koenig S., Gerstner T., Keller A., Teich M., Longin E., Dempfle C.-E. High incidence of vaproate-induced coagulation disorders in children receiving valproic acid: a prospective study. Blood Coagul. Fibrinolysis, 2008, vol. 19, no. 5, pp. 375-382. DOI: 10.1097/ MBC.0b013e3282f3f9ec.

11.Esfahani P.N., Nasiri J., Badihian S., Yaghini O. Short-Term Side Effects of Low Dose Valproate Monotherapy in Epileptic Children: A Prospective Study. Iran J. Child. Neurol., 2019, vol. 13, no. 2, pp. 37-46.

12.Star K., Edwards I.R., Choonara I. Valproic acid and fatalities in children: a review of individual case safety reports in VigiBase. PLoS One, 2014, vol. 9, no. 10, pp. e108970. DOI: 10.1371/journal.pone.0108970.

13.Geodakian O.S. Sistemnaia toksichnost mestnykh anestetikov u detei [Systemic toxicity of local anesthetics in children]. Anesteziol. Reanimatol., 2014, vol. 59, no. 5, pp. 53-56. (in Russian)

14.Shaikh S.I., Hegade G. Role of Anesthesiologist in the Management of a Child with Cerebral Palsy. Anesth. Essays Res., 2017, vol. 11, no. 3, pp. 544-549. DOI: 10.4103/0259-1162.194569.

15.Hasanov F.J., Aslanov A.A., Muradov N.F., Namazova K.N. Osobennosti techeniia kombinirovannoi anestezii s epiduralnym komponentom v zavisimosti ot tipa vegetativnoi nervnoi sistemy [Features of the course of combined anesthesia with epidural component depending on the type of autonomic nervous system]. Anesteziol. Reanimatol., 2016, vol. 61, no. 1, pp. 23-27. (in Russian)

16.Rawal N. Epidural technique for postoperative pain: gold standard no more? Reg. Anesth. Pain Med., 2012, vol. 37, no. 3, pp. 310317. DOI: 10.1097/AAP.0b013e31825735c6.

17.Sichkar S.Yu., Afukov I.I., Stepanenko S.M. Epiduralnaia analgeziia u novorozhdennykh v perioperatsionnom i posleoperatsionnom periode [Epidural analgesia for intraoperative and postoperative care in newborns]. Anesteziol. Reanimatol., 2015, vol. 60, no. 3, pp. 65-70. (in Russian)

18.Israelian L.A., Lubnin A.Iu., Tseitlin A.M., Stepanenko A.Iu., Kazarian A.A., Golovteev A.L., Melikian A.G. Narusheniia gemostaza, obuslovlennye khronicheskim priemom valproevoi kisloty u neirokhirurgicheskikh bolnykh. Kontrol s pomoshchiu tromboelastografii [Hemostatic disorders caused by chronic use of valproic acid in neurosurgical patients. Thromboelastographic monitoring]. Anesteziol. Reanimatol., 2010, no. 4, pp. 50-54. (in Russian)

19.Zighetti M.L., Fontana G., Lussana F., Chiesa V., Vignoli A., Canevini M.P., Cattaneo M. Effects of chronic administration of valproic acid to epileptic patients on coagulation tests and primary hemostasis. Epilepsia, 2015, vol. 56, no. 5, pp. e49-e52. DOI: 10.1111/epi.12952.

20. Order of the RF Ministry of Health of April 1, 2016 no. 200n, Ob utverzhdenii pravil nadlezhashchei klinicheskoi praktiki [About approval of the rules of proper clinical practice]. (in Russian). Available at: https://base.garant.ru/71473446/\#block_3 (accessed 17.07.2019).

21.Piliugina M.S. Puti metabolizma preparatov valproevoi kisloty i karbamazepina [Metabolism pathways of valproic acid and carbamazepine]. Vestnik Klinicheskoi Bolnitsy No 51, 2010, vol. 3, no. 10, pp. 52-55. (in Russian)

22.Shnaider N.A, Dmitrenko D.V. Khronicheskaia intoksikatsiia valproevoi kislotoi v epileptologii: diagnostika i lechenie [Chronic intoxication with valproic acid in epileptology: diagnosis and treatment]. Nevrologiia, Neiropsikhiatriia, Psikhosomatika, 2016, vol. 8, no. 2, pp. 94-99. (in Russian)

23.Lheureux P.E., Hantson P. Carnitine in the treatment of valproic acid-induced toxicity. Clin. Toxicol., 2009, vol. 47, no. 2, pp. 101111. DOI: $10.1080 / 15563650902752376$.

24.Bachmann T., Bertheussen K.H., Svalheim S., Rauchenzauner M., Luef G., Gjerstad L., Taubøll E. Haematological side effects of antiepileptic drug treatment in patients with epilepsy. Acta Neurol. Scand. Suppl., 2011, no. 191, pp. 23-27. DOI: 10.1111/j.16000404.2011.01539.x.

25.Schmid M.M., Freudenmann R.W., Keller F., Connemann B.J., Hiemke C., Gahr M., Kratzer W., Fuchs M., Schönfeldt-Lecuona C. Non-fatal and fatal liver failure associated with valproic acid. Pharmacopsychiatry, 2013, vol. 46, no. 2, pp. 63-68. DOI: $10.1055 / \mathrm{s}-0032-1323671$.

26.Ecoffey C., Lacroix F., Giaufré E., Orliaguet G., Courrèges P.; Association des Anesthésistes Réanimateurs Pédiatriques d'Expression Française (ADARPEF). Epidemiology and morbidity of regional anesthesia in children: a follow-up one-year prospective survey of the French-Language Society of Paediatric Anaesthesiologists (ADARPEF). Paediatr. Anaesth., 2010, vol. 20, no. 12, pp. 10611069. DOI: $10.1111 / \mathrm{j} .1460-9592.2010 .03448 . x$.

Received: 17.03 .2020

\section{Information about the authors:}

1. Vadim V. Evreinov, M.D.,

Ilizarov National Medical Research Centre for Traumatology and Orthopedics, Kurgan, Russian Federation,

Email: Evreinov2020@mail.ru

2. Tatiana A. Zhirova, M.D., Ph.D., V.D. Chaklin Ural Institute of Traumatology and Orthopedics, Ekaterinburg, Russian Federation 